\title{
Barriers to Sustainable Construction in the Ghanaian Construction Industry: Consultants Perspectives
}

\author{
Susan Dzifa Djokoto ${ }^{1}$, John Dadzie $^{1} \&$ Eric Ohemeng-Ababio ${ }^{2}$ \\ ${ }^{1}$ Kumasi Polytechnic, Faculty of Built and Natural Environment, Department of Building Technology, Kumasi, \\ Ghana \\ ${ }^{2}$ University of Education, Winneba, Kumasi Campus, Ghana \\ Correspondence: Susan Dzifa Djokoto, Kumasi Polytechnic, Faculty of Built and Natural Environment, \\ Department of Building Technology, P. O. Box 854, Kumasi, Ghana. Tel: 233-244-708-078. E-mail: \\ susdjokoto@yahoo.co.uk
}

Received: November 11, 2013 Accepted: December 6, 2013 Online Published: January 23, 2014

doi:10.5539/jsd.v7n1p134 URL: http://dx.doi.org/10.5539/jsd.v7n1p134

\begin{abstract}
This research paper aims at examining the concept of sustainability in the Ghanaian construction industry with the objective of identifying possible barriers to sustainable construction in the Ghanaian construction industry. Consequently, research data was collected through a questionnaire survey of randomly selected professionals in the construction industry in Ghana. Data collected was mainly analyzed using Relative Importance Index to rank barriers identified. The results show that key barriers to sustainable construction are lack of demand for sustainable buildings, lack of strategy to promote sustainable construction, higher initial cost, lack of public awareness and lack of government support.
\end{abstract}

Keywords: sustainability, sustainable construction, barriers, construction industry

\section{Introduction}

Decades of population growth, migration, and settlement have changed dramatically the face of Sub-Saharan Africa region. By the year 2025, the population is expected to be more than 1 billion (1,000 million) people. This rate of rapid population growth with its corresponding industrialization has led to an expansion of infrastructure in the built environment. Naturally this expansion leads to an increase in infrastructural project contributing immensely to the national economy. Globally, the construction industry constituents more than half of the national capital of most countries and represents as much as $10 \%$ of GNP. This sector accounts for around one-tenth of the world's GDP, and creates at least 7\% of its jobs (Halls, 2003). Ahadzie et al. (2009) acknowledge that construction contributes to the national socioeconomic development by providing significant employment opportunities. Beyond that, the industry provides the infrastructure and facilities required for other sectors of the economy to flourish such as; schools for education and training, factories and shops for commercial and business activities, housing for basic human needs, hospitals for health care, buildings for the national communications network and so on. In meeting these roles, the construction industry exerts enormous demand pressures on global natural resources. Cement production alone contributes greatly to the emission of $\mathrm{CO}_{2}$ into the environment. For every ton of cement produced, approximately a ton of carbon dioxide is released into the atmosphere. The contribution of concrete is twice the total of all building materials put together. Steel is also one of the most energy-intensive materials and for that reason contributes immensely to climate change. The usage of these materials leads to the destruction of the environment, through pollution (both in extracting raw materials and construction of building), dust and hazardous contamination through toxic waste (CIB Report, 1999). Half of all waste materials are due to building activities, including soil movements, generating immense transport. The construction sector is therefore a major consumer of non-renewable resources, a substantial source of waste, a polluter of air and water, and an important contributor to land dereliction (Wallbaum \& Buerkin, 2003). However, it is possible these shortfalls could be reduced if not eliminated if the construction industry adopts sustainable measures and construction processes. This is because there have been greater awareness about the effect of construction on the environment over the years. According to BRE (2004), as awareness of the potential environmental impacts of building construction grows, efforts are being made to avoid these adverse effects and to work towards impact mitigation. There is a growing consensus that appropriate strategies and 
actions are needed to make buildings and construction activities more sustainable (BSRIA, 1998; DETR, 1998; CIB, 1998; CRISP, 1998; Barrett et al., 1999).

There is also a more optimistic and positive response to calls for promoting sustainability in construction and design techniques (Morton, 2008). Due to the many benefits associated with sustainable design and construction, public governments and their agencies are increasingly incorporating sustainable design and construction practices into not only new buildings, but also existing buildings constructed (Ahn, 2013). In spite of these benefits, unsustainable design and construction processes as well as constant degradation of the environment for construction purposes still exist in most developing countries, of which Ghana is no exception. Murillo-Luna et al. (2011) identified scarcity of information and lack of clarity on environmental legislation, rigidity of legislation and bureaucratic complexity, limited development of the environmental supply sector, high cost of environmental services/technologies, and difficulties derived from competitive pressure as possible barriers to the adoption of proactive environmental strategies. Lam et al. (2010) discussed factors hindering successful implementation of green specification in construction. The factors identified are; lack of green technology and techniques, reliability and quality of specification, leadership and responsibility, stakeholder involvement, and guide and benchmarking systems. More recently, there has been growing interest in empirically analyzing the extent to which such barriers hinder development of sustainable construction (Samari et al., 2013; Hoffman \& Henn, 2008; Bon \& Hutchinson, 2013; Ayarkwa et al., 2010). According to (Häkkinen \& Belloni, 2011; Zhang et al., 2011; Ahn et al., 2013), although various steps have been taken by the developed world to fully practice sustainable construction, there exist barriers. The situation could even be more serious in this part of undeveloped world if there exist barriers to sustainable design and construction in the developed world. Therefore, the objective of this research is to identify barriers perceived by professional (consultants) as hindering effective adoption of sustainable construction in the Ghanaian construction industry.

\section{Literature Review}

\subsection{Sustainable Construction}

Sustainable construction can be defined as 'the creation and responsible management of a healthy built environment based on the prudent use of resources and ecological principles' (Kibert, 1994). Sustainable construction ethos require a 'cradle to grave' appraisal of project, which involves managing the serviceability of project during its life-time and eventual deconstruction' focus on the economic aspect of sustainability (Wyatt, 1994). Thus a sustainable construction will aim at achieving set down principles.

\subsection{Principles of Sustainable Construction}

There are six principles for sustainable construction, proposed by Miyakate (1996); CIB (1996)

- Minimization of resource consumption;

- Maximization of resource reuse;

- Use renewable and recyclable resources;

- $\quad$ Protect the natural environment;

- Create a healthy and non-toxic environment; and

- Pursue quality in creating the built environment.

\subsection{Barriers Towards Sustainable Construction}

In order to endorse and drive the agenda of sustainable construction within the Ghanaian Construction Industry, the barriers that impede these practices must first be identified. The barriers identified in literature can be grouped into four primary categories: cultural, financial, steering and professional barriers.

\subsubsection{Cultural Barriers}

The Ghanaian construction industry process has been used over the past decades as such it presents itself as a sector which is traditionally very difficult to change especially with respect to construction methods practiced and building materials used. Construction in Ghana favours the use of blocks and reinforced concrete and discourages any other alternative to these building materials and services. This illustrates a typical change resistance; a major barrier. This change resistance results in a lack of demand by clients and stakeholders of construction projects affecting its eventual supply. Williams and Dair (2006), in that same vain identified lack of sustainability measure by stakeholder as by far the most commonly recorded barrier and further stated the lack of demand by the client as a commonly recognized barrier. Lack of demand was also cited as the most significant 
barrier by eighty-four per cent (84\%) of respondents as a building project cannot be done along sustainable lines without the owner or developer's "full support for sustainable concepts" (Landman, 1999; Ahn et al., 2013).

This can nevertheless be overcome by client demand and willingness as found in the UK where pioneering of sustainable buildings has often been procured by owner- occupiers who are less constrained by market norms. The Toronto Green Development Standard (2006) also acknowledges that public awareness about green building has been an important component that led to high demand. Thus a continual public awareness of sustainable concepts on sustainable construction and its benefits will lead to an increased demand compelling products to be tailored to their needs to be produced.

\subsubsection{Financial Barriers}

The fear of higher investment costs for sustainable buildings compared with traditional building and the risks of unforeseen costs are often addressed as barriers for sustainable buildings (Häkkinen \& Belloni, 2011). The adoption of sustainable building solutions may be hindered because clients are concerned about the higher risk (Hydes \& Creech, 2000; Larsson \& Clark, 2000; Nelms et al., 2005) based on unfamiliar techniques, the lack of previous experience, additional testing and inspection in construction, a lack of manufacturer and supplier support, and a lack of performance information. These costs are also high as according to Bartlet and Howard (2000), cost consultants overestimated the capital cost and underestimated the potential cost savings. Hydes and Creech (2000) further highlight that these higher costs may be as a result of increases in the consultant's fees and indirectly from the unfamiliarity of the design team and contractors with sustainable building methods.

Even though it's a known fact that sustainable practices in construction are estimated to increase initial capital cost generally in the range of $1-25 \%$, this can often be offset by significant savings in the operational costs (Kats, 2003). However, life-cycle thinking is critically applied to this practice, developers and building owners will appreciate and receive the benefits or those benefits are rapidly discounted. Sustainability will not only reduce life-cycle cost but also increase productivity of staff using the building (Wargocki, 2000).

\subsubsection{Capacity/Professional Barriers}

The most critical barrier to sustainable construction is the lack of capacity of the construction sector to actually implement sustainable practices (CIB Report, 1999). This is further reiterated by Häkkinen and Belloni (2011) that sustainable buildings can be hindered by ignorance or a lack of common understanding about sustainability. Rydin et al. (2006) claim that while designers demonstrate confidence in their ability to access and use knowledge in general, this confidence falls when sustainable building issues are addressed. This presupposes that professionals within the built environment need to be fully acquainted with sustainable construction principles in order to implement its practice. Not only are they supposed to be knowledgeable, these professionals need to form an integrated team from conception to inception comprising of the developer/owner, project manager, contractor, architect, services engineer, structural engineer, civil engineer, environmental engineer, landscape consultant, cost planner and building surveyor. This team needs to have the best available information on products and tools to achieve sustainable construction however Williams and Dair (2006) identified that, this was not the case. In their research, evidence of hindrance due to a lack of information was an experience common to most stakeholder groups. In several cases, stakeholders admitted to not being aware of sustainable measures or alternatives that fall within their remit. Similarly, installing sustainable technologies and materials requires new forms of competencies and knowledge, yet it was evident from the research that not all those with responsibilities in this area had the necessary experience or expertise to meet the challenge.

The workforce of every industry is its back bone as such the need to involve professionals who are not only knowledgeable but can promote sustainable construction working as a team. This barrier if unattended will indicate a considerable knowledge and skills gap in the construction sector.

\subsubsection{Steering Barriers}

A major characteristic of the construction industry is the involvement of a large number of individuals ranging from clients to the builder thus an effective steering or strategy will be required to implement sustainable construction. The lack thereof or wrongful steering may rather stifle sustainable construction whilst on the other hand, steering measures can promote it. Steering barriers include but not limited to the lack of building codes, government policies/support and measurement tools amongst others. On the contrary, a new kind of orchestrating and pioneering role of the building authorities and other public actors in the building sector is called for (Rohracher, 2001). Measurement tools have been developed in some advanced countries to measure the application of sustainable principles in buildings. Popular amongst them is the LEED for the US and 
BREEAM for the UK. The lack of methods is a barrier, but methods as such do not improve the sustainability of built environment. The impact will depend on the implementation of methods (Häkkinen \& Belloni, 2011).

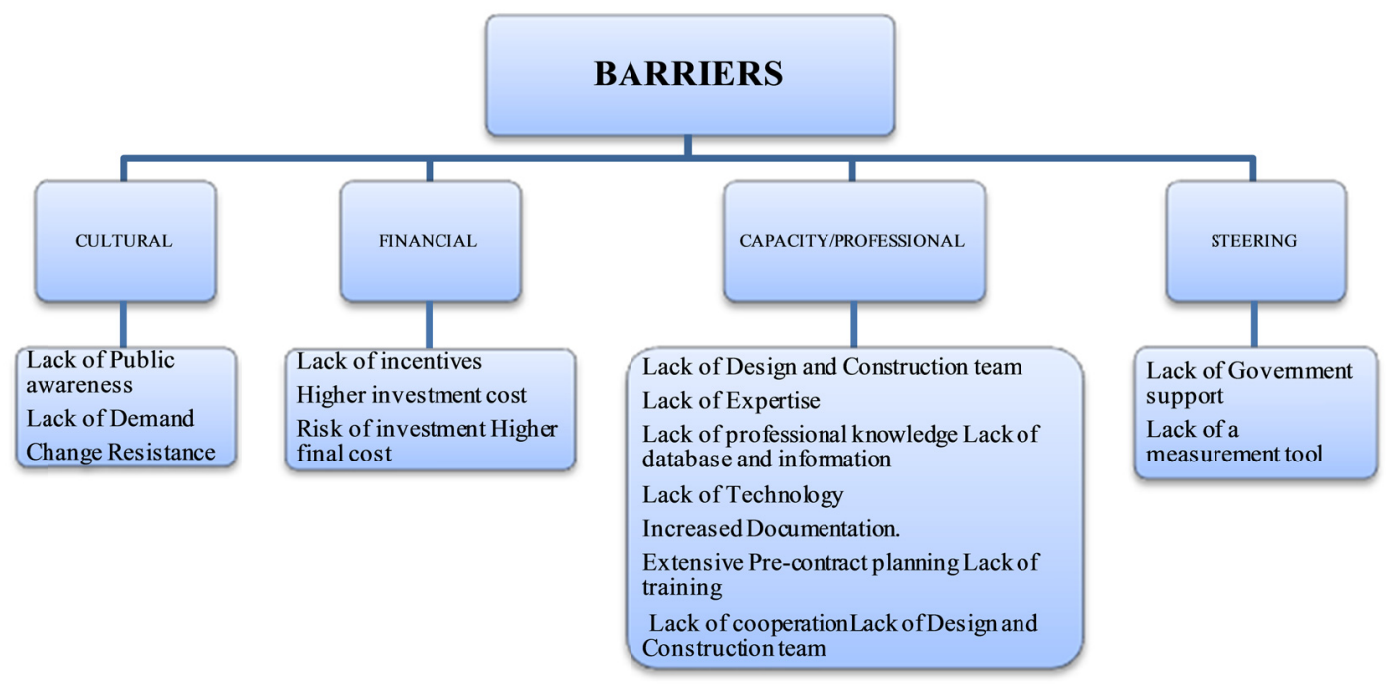

Figure 1. Barriers to sustainable construction

\section{Method}

A comprehensive literature review on barriers to sustainable construction was carried out, a pre-survey questionnaire was developed. These barriers have been addressed in previous studies which were compiled into a list, as presented in Table 1. The pre-survey questionnaire aimed to validate 42 barriers that had been identified through literature review. In addition, interviews with experts in the industry were conducted to fine-tune the list of barriers to sustainable construction in the Ghanaian construction industry. To highlight the barriers identified, pre-survey interviews were also conducted. The results enhanced the understanding of the rationale for the barriers that were to be included in the survey. Professionals who have registered with their professional institutions (Ghana Institution of Engineers, Ghana Institution of Surveyors, Ghana Institution of Architects, etc.) were engaged. Also considered was their working experience. Five professionals from each professional body having more than 10 years of experience in managing construction projects and for that matter sustainable construction were interviewed. The reason for the main survey was to discover and establish key barriers they encountered in sustainable construction. The results from the pre-survey and interviews served as a basis in developing the main survey questionnaire. Consequently the figure was trimmed down from 42 to 20 and was used to carry out the survey. The first section of the survey questionnaire captured the respondent's profile. The structure of the questionnaire mainly includes the major barriers of applying barriers to sustainable construction projects Ghana. The respondents were asked to rate the extent to which each of the barrier affects sustainable construction using a 5-point Likert scale.

Out of the 200 questionnaires sent out, 62 sets of completed survey questionnaires were received and analyzed. The response rate was relatively low because those that were not completed or properly answered were rejected. In addition only responses from respondents who had experience and had clear understanding of sustainable construction were used. Under the respondent's profile the information sought were professional background, year of experience and type of projects respondents usually undertake in their individual companies. The results indicate that, twenty-five (25) respondents representing 34\% of the sample size were Architects with thirteen (13) respondents being Civil/Structural Engineer, fifteen (15) were Quantity Surveyor and nine (9), Project/Construction Manager. None of the respondents had years of experience above 20 years. The survey revealed that out of the sixty-two responses received $22 \%, 14 \%, 56 \%$, and $8 \%$ have been in construction industry for less than 2years, between 2-5years, 6-10years, and 11-20years respectively.

\subsection{Analysis of Data}

The data provided by the respondents in the questionnaire was presented and analyzed using the Relative Importance Index (RII). The Relative Importance Index (RII) was also used to rank barriers affecting the 
implementation of sustainable construction in Ghanaian construction industry. The Index is computed in Adnan et al. (2007) as:

$\mathrm{RII}=\frac{5 \mathrm{n} 5+4 \mathrm{n} 4+3 \mathrm{n} 3+2 \mathrm{n} 2+\mathrm{n} 1}{5(\mathrm{n} 5+\mathrm{n} 4+\mathrm{n} 3+\mathrm{n} 2+\mathrm{n} 1)}$

Where: $\mathrm{n} 1$ - number of respondents who answered "strongly disagree" or "very low"

$\mathrm{n} 2$ - number of respondents who answered "disagree" or "low"

n3 - number of respondents who answered "neutral" or "medium"

n4 - number of respondents who answered "agree" or "high"

n5 - number of respondents who answered "strongly agree" or "very high"

\section{Results and Discussion}

\subsection{Barriers to Sustainable Construction}

Table 1. Barriers that affect sustainable construction in the Ghanaian construction industry

\begin{tabular}{llcc}
\hline Item & Barriers to sustainable construction & Relative Important Index(RII) & RANK \\
\hline 1 & Lack of Building Codes and Regulation & 0.74 & $\mathbf{8}^{\text {th }}$ \\
2 & Lack of incentives & 0.63 & $\mathbf{1 5}^{\text {th }}$ \\
3 & Higher investment cost & 0.72 & $\mathbf{9}^{\text {th }}$ \\
4 & Risk of investment & 0.76 & $7^{\text {th }}$ \\
5 & Higher final cost & 0.82 & $\mathbf{3}^{\text {rd }}$ \\
6 & Lack of Public awareness & 0.79 & $\mathbf{4}^{\text {th }}$ \\
7 & Lack of Demand & 0.90 & $\mathbf{1}^{\text {st }}$ \\
8 & Lack of strategy to promote sustainable construction & 0.87 & $\mathbf{2}^{\text {nd }}$ \\
9 & Lack of Design and Construction team & 0.56 & $\mathbf{1 7}^{\text {th }}$ \\
10 & Lack of Expertise & 0.54 & $\mathbf{1 8}^{\text {th }}$ \\
11 & Lack of professional knowledge & 0.44 & $\mathbf{2 0}^{\text {th }}$ \\
12 & Lack of database and information & 0.63 & $\mathbf{1 6}^{\text {th }}$ \\
13 & Lack of Technology & 0.52 & $\mathbf{1 9}^{\text {th }}$ \\
14 & Lack of Government support & 0.78 & $\mathbf{5}^{\text {th }}$ \\
15 & Lack of a measurement tool & 0.68 & $\mathbf{1 0}^{\text {th }}$ \\
16 & Increased Documentation & 0.64 & $\mathbf{1 3}^{\text {th }}$ \\
17 & Extensive Pre-contract planning & 0.65 & $\mathbf{1 2}^{\text {th }}$ \\
18 & Change Resistance & 0.64 & $\mathbf{1 4}^{\text {th }}$ \\
19 & Lack of training & 0.67 & $\mathbf{1 1}^{\text {th }}$ \\
20 & Lack of cooperation & 0.77 & $\mathbf{6}^{\text {th }}$ \\
\hline & & &
\end{tabular}


Table 2. Highly ranked barriers

\begin{tabular}{llcc}
\hline Item & Barriers to sustainable construction & Relative Important Index(RII) & RANK \\
\hline 1 & Lack of Demand & 0.90 & $\mathbf{1}^{\text {st }}$ \\
2 & Lack of strategy to promote sustainable construction & 0.87 & $\mathbf{2}^{\text {nd }}$ \\
3 & Higher final cost & 0.82 & $\mathbf{3}^{\text {rd }}$ \\
4 & Lack of Public awareness & 0.79 & $\mathbf{4}^{\text {th }}$ \\
5 & Lack of Government support & 0.78 & $\mathbf{5}^{\text {th }}$ \\
6 & Lack of cooperation & 0.77 & $\mathbf{6}^{\text {th }}$ \\
7 & Risk of investment & 0.76 & $\mathbf{7}^{\text {th }}$ \\
8 & Lack of Building Codes and Regulation & 0.74 & $\mathbf{8}^{\text {th }}$ \\
9 & Higher investment cost & 0.72 & $\mathbf{9}^{\text {th }}$ \\
10 & Lack of a measurement tool & 0.68 & $\mathbf{1 0}^{\text {th }}$ \\
\hline
\end{tabular}

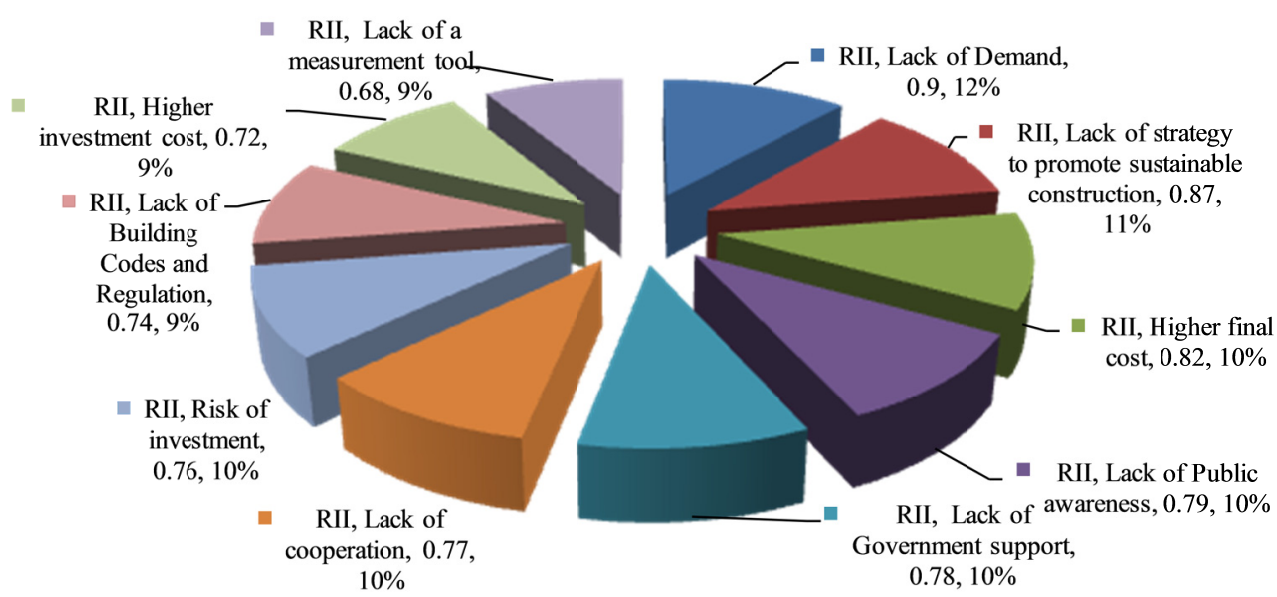

Figure 2. Highly ranked barriers

Major barriers identified by respondents have been shown and expressed in Table 4 and Figure 2. The responses by key players indicate that Lack of Demand with RII of 0.90, Lack of strategy to promote sustainable construction, RII of 0.87 ranked 2nd, Higher final cost ranked 3rd with RII of 0.82, Lack of public awareness ranked 4th with RII of 0.79 and Lack of government support also ranked 5th with RII of 0.78. The others are lack of cooperation with RII 0.77 , risk of investment with RII of 0.76 , lack of building codes and regulations with RII of 0.74, High investment cost with RII of 0.72 and lack of a measurement tool also with RII of 0.68 for 6 th, 7th, 8th, 9th and 10th respectively. However, lack of expertise (0.53), lack of technology (0.52) and lack of professional knowledge (0.44) are the least in ranking with respect to the barriers that affect the implementation of sustainable construction 18th, 19th and 20th respectively as shown in Table 2.

Naturally demand leads to supply. As demand increases, it pushes supply to also go up. Generally there is lack of demand from clients and customers when green market is still at initial stage (Zhang et al., 2011). This result confirms Williams and Dair (2007) position and it is consistent with (Anderson et al., 2000; Davis, 2001; Landman, 1999; Owen, 2003) assertion that most clients are not convinced there is the need to demand for such green buildings. There is an urgent need for demand of sustainable construction because the demand and willingness of clients eventually determine the development of and also the extent to which sustainable construction can be used (Häkkinen \& Belloni, 2011). Albeit demand is closely related to such issues as supply, only few clients and customers may have a significant desire to own sustainable buildings (SBs) (Bon \& Hutchinson, 2000), but Bordass (2000) found that UK's pioneering SBs have often been procured by owner-occupiers who are less constrained by market norms. The result further strengthens earlier claim that clients do not ask for sustainable construction. Rao and Brownhill (2001) posit that the ideas of the circle of blame game still persist: 'designers and contractors say clients don't ask for it, clients say designers don't provide it'. 
Lack of strategy to promote sustainable construction was ranked second. There must be a policy on sustainable construction which indicates clearly when, how and who enforces what. In Ghana, even which is such a policy, the will to properly enforced it is always a problem. A sustainable policy seeks to drive forward the sustainable construction by providing clarity around the existing policy framework, signaling the future direction of Government policy and showing what can be done towards making sure they are enforced. The lack of steering or the wrong type of steering may hinder sustainable construction (Häkkinen \& Belloni, 2011). Furthermore, sustainable construction can also be promoted at least to a certain extent with the help of right policies and regulations. The fragmented nature of the sector and the high number of actors involved may lead to a situation where regulations are considered as the only possible way to proceed (Femenias, 2005). A combination of legislations or policies to enforce companies and market to sustainable development and incentive package for construction firms that practice sustainability in their projects is the best approach that can be applied as a strategy tailored towards sustainable construction (Samari, 2013).

According to Rehm and Ade (2013) green building construction costs is higher on average, although the difference was not statistically significant than conventional buildings. Also Kats et al. (2003) emphasis that the average cost premium of sustainable construction over just building to code is less than $2 \%$. Most at times new ideas, systems and components are considered expensive. This therefore leads to the general apathy attached to such products. According to the results, higher final cost was ranked the third barrier. This result confirms (Zhang et al., 2011) position that cost is considered as the biggest barriers in promoting green strategy in real estate development process. Again, Bandy et al. (2007) posit that that higher upfront cost (new design, technology and construction method) is the main impediment to green building development. Furthermore, using green materials would cost between 3 to 4 percent more than using conventional construction materials (Urban Land Institute., 2002). According to Williams and Dair (2007) the cost of proving environmentally green features and developments was significantly higher than for standard schemes. If the construction costs for green real estate do exist, what method can be adopted to control this conflict of interest? Who is willing to pay this extra cost? (Zhang et al., 2011). Furthermore, according to Zhang et al. (2011) financial cost is usually considered as the critical barrier for real estate developers who are hesitating whether to develop green real estate project or not.

Public awareness about green building has been an important component that led to high demand (Toronto green development standard, 2006). Improving Sustainable construction among construction professionals in Ghana was identified necessary. Observations in most of major cities in the country show how some designs are deemed not sustainable, thereby leading to high energy demand, the emission of $\mathrm{CO}_{2}$ etc. The design phase lacks powerful methods (de Jonge, 2005). The materials and methods are just not sustainable. This is as a result of the lack of awareness with respect to sustainable construction. SB can be hindered by ignorance or a lack of common understanding about sustainability (Häkkinen \& Belloni, 2011). Also the results go to emphasis Rydin et al. (2006) claim that while designers demonstrate confidence in their ability to access and use knowledge in general, this confidence falls when SB is addressed. Clearly the lack of awareness is a serious barrier. This is because Mills and Glass (2009) enforce it by stating that the ability of construction design managers to integrate sustainability into building design; it requires that the sustainability issues are clearly communicated in a project's brief. Ala-Juusela et al. (2006) claim that especially in the residential sector the lack of information is a problem for energy-efficient building. The normal house builder who makes the decisions about energy systems has often very little knowledge about energy efficiency.

According to (Atsusaka, 2003; Samari, 2012) the role of governments in promoting green building is undeniable and effective. Rules and regulations should be replaced with enforcing new ones to support green building development. Governments can facilitate green building development by a variety of instruments. According to (Fisher et al., 1989; Sutherland, 1991; Golove et al., 1996; Varone et al., 2000; Ofori, 2006) governments have important role to promote green building. Naturally for a developing country like Ghana, the need to have a government ready to lead in the provision of sustainable construction is vital and critical. The result indicates that the lack of maximum support from government is a major barrier to the adoption and use of sustainable construction processes. Government should be a key player in terms of promoting green building in the construction industry. Government can affect the construction industry by a variety of instruments. Regulatory and incentive instruments are the main tools for governments to develop green building (Yung et al., 2002).

\section{Conclusions and Recommendation}

This paper was set out to identify barriers to sustainable construction in the Ghanaian construction industry. Consequently, this paper has identified, the top ten barriers to sustainable construction encountered as lack of demand, lack of strategy to promote sustainable construction, higher final cost, lack of public awareness and lack 
of Government support. The others are lack of cooperation, risk of investment, lack of Building Codes and Regulation, higher investment cost and lack of a measurement tool. Therefore, key barriers identified are related to lack of knowledge of green technologies, lack of green awareness and expertise and lack of government support. In line with this, an improvement of skills in this sector is required. This suggests that there is a need for policy and regulations on green issues, which may be achieved by the initiatives promoted by government. Furthermore, there is another urgent need to stimulate demand for sustainable construction in the construction industry in Ghana.

\section{References}

Adnan, H., Jusoff, K., \& Salim, M. K. (2008). The Malaysian Construction Industry's Risk Management in Design and Build. Journal of Modern Applied Science, 2(5), 27-33.

Ahadzie, D. K., Proverb, D. G., Olomolaiye, P. O., \& Ankrah, N. A. (2009). Competences required by managers for housing construction in Ghana - Implications for CPD agenda. Emerald, 16(4).

Ahn, Y. H., Pearce, A. R., Wang, Y., \& Wang, G. (2013). Drivers and barriers of sustainable design and construction: The perception of green building experience. International Journal of Sustainable Building Technology and Urban Development, 4(1), 35-45. http://dx.doi.org/10.1080/2093761X.2012.759887

Ala-Juusela, M., Huovila, P., Jahn, J., Nystedt, A., \& Vesanen, T. (2006). Energy Use and Greenhouse Gas Emissions from Construction and Buildings. Final report provided by VTT for UNEP. Parts of the text published in: UNEP (2007) Buildings and Climate Change Status, Challenges and Opportunities, Paris, UNEP.

Anderson, S., Bennett, R., \& Collopy, C. (2000). G-rated: Assessing the NEED for GREEN building design and construction sector survey results. Office of Sustainable Development - Green Building Division, Portland, Oregon.

Atsusaka, N. (2003). Growing the Green Building Industry in Lane County - a report for the lane county sustainable business and job project, report prepared from the program for Watershed and Community Health, Institute for a Sustainable Environment, University of Oregon, USA.

Ayarkwa, J., Ayirebi-Dansoh, \& Amoah, P. (2010). Barriers to implementation of EMS in the construction industry in Ghana. International Journal of Engineering Science, 2(4).

Bandy, R., Danckaert, C., Fetscher, G., Holmes, B., Gale, M., Mirsky, M., \& Stewart, S. (2007). Leed in upstate New York: an exploration of barriers, resources and strategies. USGBC New York Upstate chapter and environment finance center, EPA region 2, Maxwell capstone project.

Bon, R., \& Hutchinson, K. (2000). Sustainable construction: some economic challenges. Building Research \& Information, 28(5-6), 310-314. http://dx.doi.org/10.1080/096132100418465

CIB Report Publication 237, Agenda 21 on Sustainable Construction, 1999.

Davis, A. (2001). Barriers to building green. Retrieved January 12, 2013, from http://www.architectureweek.com/2001/0822/environment_1-1.html (accessed 12th January, 2013)

de Jonge, T. (2005). Cost effectiveness of sustainable housing investments. Thesis, Delft University of Technology, Delft.

De Mendonca, Landman, M. (1999). Breaking through the barriers to sustainable building - insights from building professionals on government initiatives to promote environmentally sound practices. MA thesis, Tufts University, Mass, USA.

Femenı'as, P. (2005). Demonstration Projects for SB. What's in Them for Utility?, Institution of Architecture, Chalmers University of Technology, Gothenburg.

Golove, W. H., \& Eto, J. H. (1996). Market barriers to energy Efficiency: a critical reappraisal of the rationale for public policies to promote energy efficiency, report done by Energy \& Environment Division. Lawrence Berkeley National Laboratory, University of California, USA.

Häkkinen, T., \& Belloni, K. (2011). Barriers and drivers for sustainable building. Building Research \& Information, 39(3), 239-255. http://dx.doi.org/10.1080/09613218.2011.561948

Hoffman, A. J., \& Henn R. (2008). Overcoming the Social and Psychological Barriers to Green Building. Organization \& Environment, 21(4). http://dx.doi.org/10.1177/1086026608326129 
Hydes, K., \& Creech, L. (2000). Reducing mechanical equipment cost: the economics of green design. Building Research \& Information, 28(5/6), 403-407. http://dx.doi.org/10.1080/096132100418555

Kats, G., \& Capital, E. (2003). The cost and financial benefits of green buildings: A report to California's sustainable building task force, developed for the Sustainable Building Task Force. California, USA.

Kilbert, C. J. (1994). Principles of Sustainable Construction. Proceedings of the First International Conference on Sustainable Construction, 6-9 November, Tampa, Florida, USA, Page 1-9.

Lam, P. T. I., Chan, E. H. W., Poon, C. S., Chau, C. K., \& Chun, K. P. (2010). Factors affecting the implementation of green specifications in construction. Journal of Environmental Management, 91, 654-661. http://dx.doi.org/10.1016/j.jenvman.2009.09.029

Larsson, N., \& Clark, J. (2000). Incremental costs within the design process for energy efficient buildings. Building Research \& Information, 28(5/6), 413-418. http://dx.doi.org/10.1080/096132100418573

Mills, F. T., \& Glass, J. (2009). The construction design manager's role in delivering sustainable buildings. Architectural Engineering and Design Management, 5, 75-90. http://dx.doi.org/10.3763/aedm.2009.0908

Miyatake, Y. (1996). Technology Development and Sustainable Construction. Journal of Management Engineering, 12(4), 23-27. http://dx.doi.org/10.1061/(ASCE)0742-597X(1996)12:4(23)

Morton, B. (2008). Analysing the implementation of sustainable public procurement policies, 3rd International Seminar on Public Procurement Asuncion, 1-2 Sept 2008.

Murillo-Luna, J. L., Garcés-Ayerbe, C., \& Rivera-Torres P. (2011). Barriers to the adoption of proactive environmental strategies, Journal of Cleaner Production, 19(2011), 1417-1425. http://dx.doi.org/10.1016/j.jclepro.2011.05.005

Nelms, C., Russel, A. D., \& Lence, B. J. (2005). Assessing the performance of sustainable technologies for building projects. Canadian Journal for Civil Engineering, 32, 114-128. http://dx.doi.org/10.1139/104-102

Ofori, G. (2006). Attaining sustainability through construction procurement in Singapore. CIB W092-Procurement Systems Conference 2006, Salford, UK.

Owen, C. (2003). The green field: The (sub) culture of sustainable architecture. PhD thesis, Melbourne University, Melbourne.

Rao, S., \& Brownhill, D. (2001). European green building forum 2 - green file. EU: Brussels

Rehm, M., \& Ade, R. (2013). Construction costs comparison between 'green' and conventional office buildings. Building Research \& Information, 41(2), 198-208. http://dx.doi.org/10.1080/09613218.2013.769145

Rydin, Y., Amjad, U., Moore, S., Nye, M., \& Withaker, M. (2006). Sustainable Construction and Planning. The Academic Report. Centre for Environmental Policy and Governance, The LSE SusCon Project, CEPG, London School of Economics, London.

Samari, M. (2012). Sustainable Development in Iran: A Case Study of Implementation of Sustainable Factors in Housing Development in Iran. IPEDR, 37. Singapore: ACSIT Press.

Samari, M., Godrati, N., Esmaeilifar, R., Olfat, P., \& Shafiei, M. W. M. (2013). The Investigation of the Barriers in Developing Green Building in Malaysia. Modern Applied Science, 7(2). http://dx.doi.org/10.5539/mas.v7n2p1

Sutherland, R. J. (1991). Market barriers to energy-efficient investments. Energy Journal, 12(3), 15-34. http://dx.doi.org/10.5547/ISSN0195-6574-EJ-Vol12-No3-3

$\begin{array}{llllll}\text { Toronto green development standard report. (2006). Retrieved from } & \end{array}$ http://www.toronto.ca/planning/environment/greendevelopment.htm

Varone, F., \& Aebischer, B. (2000). Energy efficiency: the challenges of policy design. Energy Policy, 29, 615-629. http://dx.doi.org/10.1016/S0301-4215(00)00156-7

Williams, K., \& Dair, C. ( 2007). What is stopping sustainable building in England? Barriers experienced by stakeholders in delivering sustainable developments. Sustainable Development, 15(3), 135-147. http://dx.doi.org/10.1002/sd.308

Woolley, T. (Ed). (2000). Green Building: Establishing Principles. Ethics and the Built Environment (pp. 44-56). Warwick Fox. Rutledge, London. 
World Commission on Environment and Development. (1987). Our common Future, London Chambers (1993), The Chambers Dictionary, Chambers Harrap Publishers Ltd., Edinburgh.

Wyatt, D. P. (1994). Recycling and Serviceability: The Twin Approach to Securing Sustainable Construction: Proceedings of First International Conference of CIB TG 16 on Sustainable Construction, Tampa, Florida, USA, 6-9 November, pp. 69-78.

Yong Han Ahn, Annie, R., Pearce, Yuhong Wang, \& George Wang. (2013). Drivers and barriers of sustainable design and construction: The perception of green building experience. International Journal of Sustainable Building Technology and Urban Development, 4(1), 35-45. http://dx.doi.org/10.1080/2093761X.2012.759887

Yung, E., \& Chan, E. H. W. (2002). Evaluating Environmental Management Policies: International Trend Development of Construction Management and Real Estate (pp.100-111).

Zhang, X. L., Shen, L. Y., Wu, Y. Zh., \& Qi, G. Y. (2011). Barriers to Implement Green Strategy in the Process of Developing Real Estate Projects. The Open Waste Management Journal, 4, 33-37. http://dx.doi.org/10.2174/1876400201104010033

\section{Copyrights}

Copyright for this article is retained by the author(s), with first publication rights granted to the journal.

This is an open-access article distributed under the terms and conditions of the Creative Commons Attribution license (http://creativecommons.org/licenses/by/3.0/). 